\title{
Nonlinear Buckling Finite Element Analysis to Estimate Collapse Pressure of Thick Cylinder under Hydrostatic Pressure
}

\author{
Jae-Hwan Lee $\oplus^{*}$, Byoungjae Park $\oplus^{* *}$ and Hyuek-Jin Choi $\oplus^{* *}$ \\ "Naval Architecture and Ocean Engineering, Chungnam National University, Daejon, Korea \\ *Korea Research Institute of Ships and Ocean Engineering, KRISO, Daejon, Korea

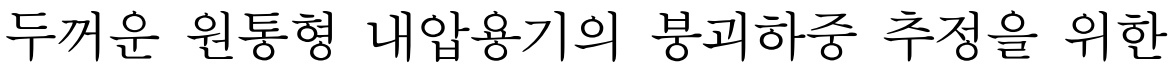 \\ 비선형좌굴 유한요소해석

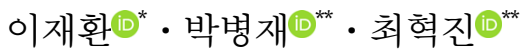 \\ *충남대학교 선박해양공학과 \\ *한국해양과학기술원 부설 선박해양플랜트연구소
}

KEY WORDS: Thick cylinder 두꺼운 실린더, Pressure vessel 내압용기, Hydraulic pressure 수압, Buckling load 좌굴하중, Collapse load 붕괴하중, Ovality 난형도, Imperfection 불완전성

\begin{abstract}
In order to perform a pressure chamber experiment with a circular cylindrical pressure vessel, the dimensions of the cylinder need to be determined in the range of the maximum externally applied pressure of the chamber to create the collapse process. In this study, the collapse load values from published chamber test results, finite element analysis and the theory of thick cylinders were thoroughly compared in a aluminum cylinder. In order to investigate the effect of collapse load according to the ovality during manufacturing, nonlinear buckling analysis was performed and the collapse load according to ovality was compared. Based on the results, the dimensions of the steel cylinder were determined for the future chamber collapse test.
\end{abstract}

\section{1. 개 요}

해양플랜트의 건설, 해양자원 탐사 및 개발 등 해저 작업의 확대에 따라 다양한 해양장비 및 로봇의 개발되고 운용되고 있 다. 일반적으로 해양장비 및 로봇의 전원, 통신 및 제어를 위한 전자장비등은 운용환경의 높은 수압으로부터 보호하기 위하여 내압용기에 탑재된다. 따라서 내압용기 설계는 외압으로부터 내부를 대기압 상태로 유지하기 위하여 다양한 해석과 실험이 필수적으로 요구된다. 내압용기는 주로 원통형이 사용되며 직 경과 두께의 비 $(D / t)$ 를 기준으로 20 이하이면 두꺼운 원통형 내 압용기로, 20 이상이면 얇은 원통형 내압용기로 분류할 수 있다. 국내의 원통형 내압용기 설계 관련 연구는 1991년 소형잠수정 (옥포6000)의 개발을 위한 심해용 압력용기 붕괴해석 연구(Shin and Yoo, 1999)를 시작으로 티타늄 Ti-6AI-4V 재료의 심해저 잠 수정용 내압용기의 항복응력, 설계압력, 외경과 두께의 확률변
수에 대한 신뢰성기반의 최적설계 연구(Jeong et al., 2006)와 동 일 내압용기의 고압챔버 실험 관련 연구(Jeong et al., 2007)가 수 행되었다. 또한 천해용 얇은 실린더의 설계(Lee et al., 2016) 및 잠수함 내압선체의 좌굴과 관련한 연구(Kim, et al., 2012; Nho, et al., 2017)등의 연구가 수행되었다. 다만, 앞서 언급한 연구들 은 대부분 얇은 원통형 내압용기를 대상으로 수행되었다. 한편, 두꺼운 원통형 내압용기와 관련한 연구는 원자로 실린더 설계 와 관련한 파손압력 추정(Yoo et al., 2010)이 있으나 주로 육상 의 원자력 분야에서 수행되고 있으며 특히 조선·해양 분야에 서는 수심 $2000 \mathrm{~m}$ 급 두꺼운 내압용기 설계를 위하여 ASME(The American Society of Mechanical Engineers) BPVC(Boiler and pressure vessel code) Section VIII 규정을 기초로 하여 초기설계 후 구조해석을 하고, 내압용기를 제작하여 내압시험과의 결과 를 비교하는 연구(Choi et al., 2016)를 수행하였으나 두꺼운 원 통형 내압용기에 대한 연구는 아직 많이 부족한 실정이다.

Received 4 January 2019, revised 27 May 2019, accepted 13 June 2019

Corresponding author Byoungjae Park: +82-42-866-3736, byoungjae@kriso.re.kr ORCID: https://orcid.org/0000-0002-8943-1477

(c) 2019, The Korean Society of Ocean Engineers

This is an open access article distributed under the terms of the creative commons attribution non-commercial license (http://creativecommons.org/licenses/by-nc/3.0) which permits unrestricted non-commercial use, distribution, and reproduction in any medium, provided the original work is properly cited. 
본 연구에서는 두꺼운 내압용기의 설계/해석/실험에 필수적으 로 요구되어지는 붕괴하중의 예측을 위하여 기 발표된 두꺼운 실린더의 붕괴하중과 관련한 다양한 이론식들을 현상에 따라 정리하고 비선형 좌굴해석을 수행하여 붕괴하중을 산출하고 기 발표된 연구 및 이론식과 비교하였다. 또한 추후 계획된 두꺼운 강철 내압용기의 압력챔버 실험을 위하여 설계치수를 검토하고 붕괴하중을 산출하였다.

\section{2. 두꺼운 실린더의 붕괴하중식}

외압을 받는 실린더의 손상과정은 좌굴을 거쳐 소성붕괴에 이르게 되므로 좌굴하중과 붕괴하중을 모두 고려해야한다. 특 히, 두꺼운 실린더의 좌굴하중은 항복이 발생하기 시작하는 하 중으로 정의되는 탄성한계하중보다 큰 경우가 많으므로 좌굴하 중, 소성붕괴하중과 함께 탄성한계하중에 대한 검토도 병행되 어야 한다. 실린더의 붕괴하중과 관련한 참고문헌들마다 사용 기호가 달라 혼동을 줄이고자 본 논문에서는 Fig. 1과 같이 사 용 기호를 통일하여 정리하였다.

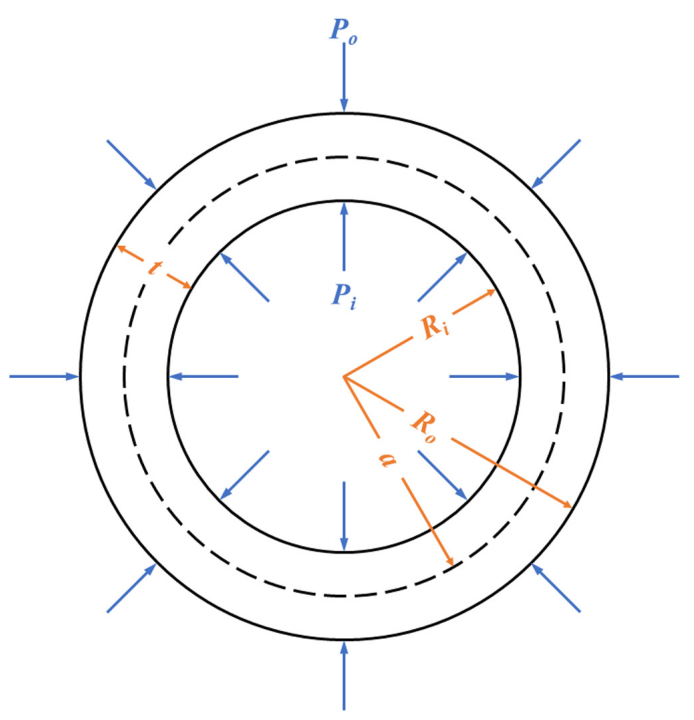

Fig. 1 Basic geometric variables

\section{1 좌굴하중}

외압을 받는 얇은 실린더의 좌굴하중은 얇은 쉘 이론(Thin shell theory)을 기반으로 도출되며 식 (1)과 같이 표현된다 (Timoshenko and gere, 1961).

$$
P_{c r}^{t s h}=\frac{1}{4} \frac{E}{1-\nu^{2}} \frac{t^{3}}{a^{3}}
$$

이때, $a$ 는 $\frac{1}{2}\left(R_{i}+R_{o}\right), t$ 는 두께, $E$ 는 탄성계수, $\nu$ 는 프와송의 비이다.

Papadakis(2008)는 얇은 실린더의 좌굴하중식은 횡전단변형 및 반경방향 응력 등의 두께에 따른 차이를 고려하지 못하기 때문에 두꺼운 실린더의 좌굴하중을 과대하게 추정한다고 하고 전단변형과 비선형 변위를 도입하고 이차 Piola-Kirchhoff응력으
로 구성된 평형방정식의 변위를 삼각함수로 가정하여 식 (2)를 도출하였다.

$$
P_{c r}=\frac{\frac{K}{a^{3}}\left(m^{2}-1\right)(1-\xi)}{1+\frac{t}{2 a}-\xi \frac{5}{12}\left[\left(1+\frac{t}{2 a}\right)-\frac{1}{m^{2}}\left(1-\frac{t}{2 a}\right)\right]}
$$

여기서, $m$ 은 정수, $K=\frac{E t^{3}}{12\left(1-\nu^{2}\right)}, \xi=\frac{K m^{2}}{K m^{2}+a^{2} \frac{5}{6} G t}$

$=\frac{\frac{t^{2}}{a^{2}} m^{2}}{\frac{t^{2}}{a^{2}} m^{2}+5(1-\nu)}$ 이다.

식 (2)의 $m=2$ 일 때, $P_{c r}$ 가 최솟값을 갖으며 두꺼운 실린더의 좌굴하중식은 식 (3)과 같이 표현된다.

$$
P_{c r(m=2)}=\frac{1}{4} \frac{E}{1-\nu^{2}}\left(\frac{t}{a}\right)^{3} \frac{\left(1-\xi_{(m=2)}\right)}{1+\frac{t}{2 a}-\xi_{(m=2)}\left(\frac{5}{16}+\frac{25}{96} \frac{t}{a}\right)}
$$

두꺼운 실린더의 좌굴하중식에 얇은 실린더 조건 $(t / a \ll 1, \xi \ll 1)$ 을 적용하면 얇은 실린더의 좌굴하중식과 같아짐을 확인할 수 있 으며 따라서 실린더의 두께와 상관없이 사용될 수 있다.

$$
P_{c r}^{t s t}=\frac{K}{a^{3}}\left(m^{2}-1\right)=\frac{1}{12} \frac{E}{1-v^{2}} \frac{h^{3}}{a^{3}}\left(m^{2}-1\right)
$$

\section{2 탄성한계 하중}

Corradi et al.(2011)는 Lamé 응력식과 von Mises 항복 응력식 을 기반으로 탄성한계 하중식을 도출하였다. 일반적인 두꺼운 실린더의 탄성영역에서의 반경방향 $\left(\sigma_{r}\right)$, 원주방향 $\left(\sigma_{\theta}\right)$ 및 축방향 응력 $\left(\sigma_{z}\right)$ 을 나타내는 Lamé 응력식은 식 (5)-(7)과 같다.

$$
\begin{aligned}
\sigma_{r} & =-P_{o} \frac{r_{o}^{2}}{r_{o}^{2}-r_{i}^{2}} \frac{r^{2}-r_{i}^{2}}{r^{2}}-P_{i} \frac{r_{i}^{2}}{r_{o}^{2}-r_{i}^{2}} \frac{r_{o}^{2}-r^{2}}{r^{2}} \\
\sigma_{\theta} & =-P_{o} \frac{r_{o}^{2}}{r_{o}^{2}-r_{i}^{2}} \frac{r^{2}+r_{i}^{2}}{r^{2}}+P_{o} \frac{r_{i}^{2}}{r_{o}^{2}-r_{i}^{2}} \frac{r_{o}^{2}+r^{2}}{r^{2}} \\
\sigma_{z} & =\frac{P_{i} r_{i}^{2}-P_{o} r_{o}^{2}}{r_{o}^{2}-r_{i}^{2}}
\end{aligned}
$$

여기서, $P_{o}$ 는 외압, $P_{i}$ 는 내압, $r_{o}$ 는 외부 반경, $r_{i}$ 내부 반경, $r$ 은 실린더의 임의의 점까지의 반지름이다.

Lamé 응력식에서 외부 압력 $\left(P_{o}\right)$ 만 있는 경우 $\left(P_{i}=0\right)$ 를 고려할 때, 실린더 내부 표면 $\left(r=r_{i}\right)$ 에서 von Mises응력이 최대가 되며 반경방향 응력 $\left(\sigma_{r}\right)$ 은 0 이 되고 원주방향응력 $\left(\sigma_{\theta}\right)$ 와 축방향 응력 $\left(\sigma_{z}=n\right)$ 만 존재하게 된다. 이때의 응력상태를 von Mises 항복응 력식에 대입하여 식 (8)과 같이 탄성한계하중식이 도출된다. 


$$
P_{o}=\sigma_{0} \frac{1}{2} \frac{r_{o}^{2}-r_{i}^{2}}{r_{o}^{2}}\left(\sqrt{1-\frac{3}{4}\left(\frac{n}{\sigma_{0}}\right)^{2}}-\frac{1}{2} \frac{n}{\sigma_{0}}\right)
$$

이때, $\sigma_{0}$ 는 재료의 항복응력이다.

식 (8)에서 축방향 하중만 존재할 경우, 붕괴는 식 (9)와 같이 축방향 응력에 의하여 결정되며, 순수한 외압만 있는 경우에는 식(10)과 같으며 축방향 응력은 0 이 된다. 또한 축방향 하중과 외압이 모두 있는 정수압(Hydrostatic pressure) 상태에서의 탄성 한계하중과 축응력은 식 (11)와 같다.

$$
\begin{aligned}
& P_{c r}=0, \sigma_{z}=n= \pm \sigma_{0} \\
& P_{c r}=\sigma_{0} \frac{t}{r_{o}}\left(1-\frac{1}{2} \frac{t}{r_{o}}\right), \sigma_{z}=n=0 \\
& P_{c r}=\frac{2}{\sqrt{3}} \sigma_{0} \frac{t}{r_{o}}\left(1-\frac{1}{2} \frac{t}{r_{o}}\right), n=-\frac{1}{\sqrt{3}} \sigma_{0}
\end{aligned}
$$

\section{3 소성붕괴하중}

Corradi et al.(2011)은 두꺼운 실린더의 경우, 소성붕괴하중 (Plastic collapse) 한계 값을 도출하기 위하여 외부하중에 의한 일과 붕괴과정에서 소성적으로 발산하는 에너지를 같게 하여 소성붕괴하중 계산하고 소성붕괴하중과 축방향 응력을 식 (12) 와 식 (13)과 같이 제시하였다.

$$
\begin{aligned}
& P_{c r}=\frac{2}{\sqrt{3}} \sigma_{u} \ln \frac{r_{o}}{r_{i}} \\
& \sigma_{z}=-\frac{2}{\sqrt{3}} \sigma_{0} \frac{r_{o}^{2}}{r_{o}^{2}-r_{i}^{2}} \ln \frac{r_{o}^{2}}{r_{i}^{2}}=-\frac{r_{o}^{2}}{r_{o}^{2}-r_{i}^{2}} P_{c r}
\end{aligned}
$$

\section{4 난형도(Ovality)의 영향}

Timoshenko and Gere(1961)에서 처음 소개된 실린더의 난형도 (Ovality or noncircularity)는 원형의 완벽함을 의미한다. 난형도 는 구조의 불안정성이 발생함을 의미하며 정도가 커지면 불안 정성이 커지므로 좌굴하중은 작아진다. 즉, 난형도에 비례하여 좌굴에 취약하다는 의미이다. Bickell and Ruiz(1967)은 Fig. 2와 같은 형태의 난형도가 있는 두꺼운 실린더의 좌굴하중식을 식 (14)-(15)와 같이 제시하였다.
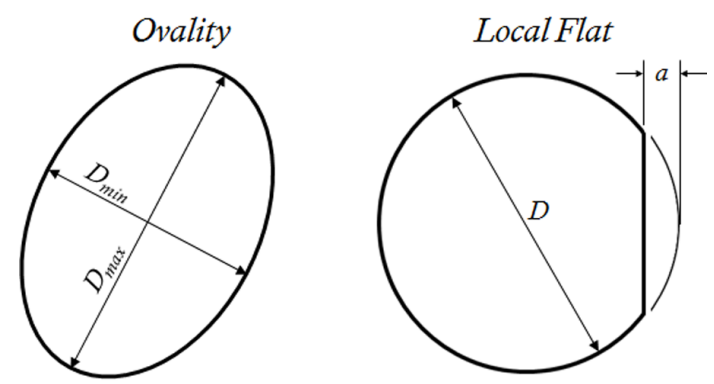

Fig. 2 Ovality of cylinder

$$
\begin{aligned}
& P_{c}^{\prime}=\frac{2 \sigma_{0} t / D}{1+\frac{1.5 u(1-0.2 D / L)}{100 t / D}}(\text { with } D / L<5) \\
& P_{c}^{\prime}=\frac{2 \sigma_{0} t}{D}\left(\text { with } \frac{D}{L}>5\right)
\end{aligned}
$$

여기서, $\sigma_{0}$ 은 항복응력, $D$ 는 평균지름을 나타내며 $u$ 는 Out-ofroundness로 다음 중 큰 값을 사용한다.

$$
u=\frac{2\left(D_{\max }-D_{\min }\right)}{D_{\max }+D_{\min }} \times 100 \text { or } u=\frac{4 a}{D} \times 100
$$

\section{3. 두꺼운 원통형 내압용기의 비선형좌굴해석}

비선형좌굴해석은 Choi et al.(2016)에서 수행한 압력챔버 실 험을 참고하여 수행하였다. Choi et al.(2016)의 실험에 사용된 덮개를 갖는 알루미늄 내압용기의 주요 제원은 Table 1 과 같으 며 직경과 두께의 비 $(D / t)$ 가 14.75로 두꺼운 실린더로 분류될 수 있다. 실험에서는 Fig. 3 과 같이 $60 \mathrm{MPa}$ 까지 가압하고 원주방 향 변형량을 측정하였다.

Fig. 4는 Choi et al.(2016)의 압력챔버 실험의 결과로 내압용기 외부 표면에서 측정된 원주방향 변형률은 압력이 $45 \mathrm{MPa}$ 까지 선형적으로 증가하다 이후 급격하게 변화하는 것으로 보아 $45 \mathrm{MPa}$ 에서 항복이 발생하고 소성변형이 발생하여 $50.5 \mathrm{MPa}$ 에서 붕괴되었다. 단, 압력챔버 실험은 덮개와 내압용기의 결합부에 틈이 발생하여 종료되었으므로 실제 붕괴하중은 더 클 것으로 예상되나 정확한 예상이 어려우므로 본 연구에서는 붕괴하중을 $50.5 \mathrm{MPa}$ 로 가정하였다. 또한 Fig. 5 와 같이 내압용기의 최종 변 형형상은 좌굴차수가 3(Lobe 3)인 형상이다.

Table 1 Dimension of cylinder (Choi et al., 2016)

\begin{tabular}{cc}
\hline \hline Outer diameter & $295.7 \mathrm{~mm}$ \\
Inner diameter & $255.7 \mathrm{~mm}$ \\
Length & $590 \mathrm{~mm}$ \\
Thickness & $20 \mathrm{~mm}$ \\
\hline
\end{tabular}

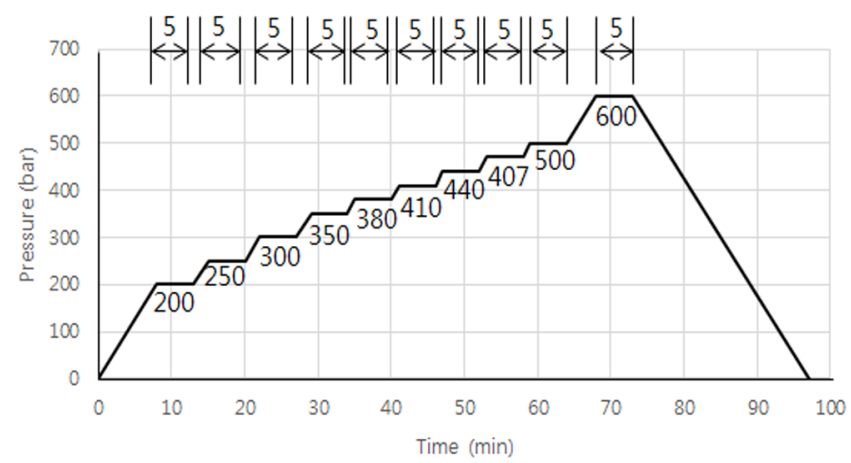

Fig. 3 Chamber test Condition (Choi et al., 2016) 


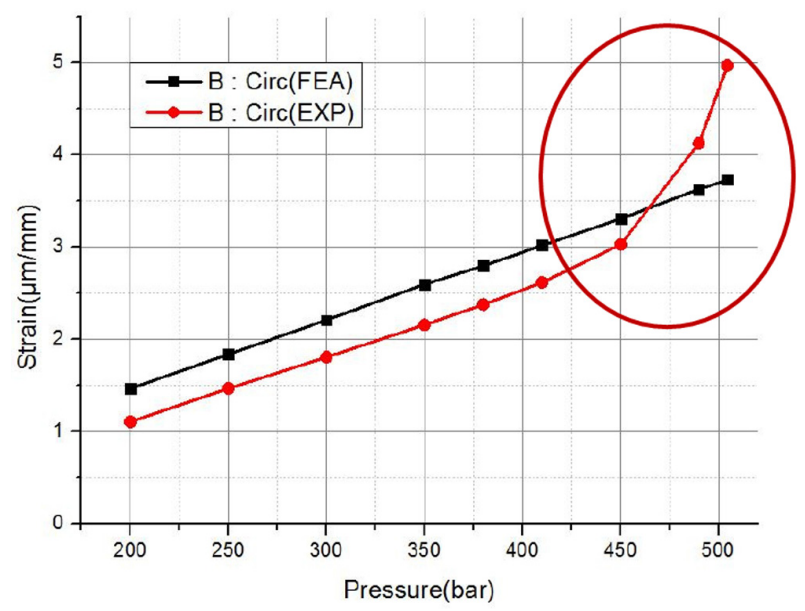

Fig. 4 Comparison of test and FEA (Choi et al., 2016)

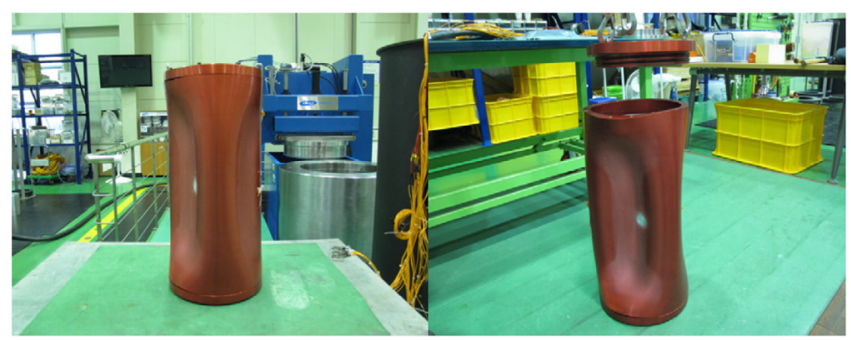

Fig. 5 Collapse of thick aluminum cylinder (Choi et al., 2016)

\section{1 비선형 좌굴해석}

비선형 좌굴해석은 완전 원형단면의 내압용기와 제작공차를 가정하여 실제 형상에 난형도를 부여한 내압용기에 대하여 수 행하고 붕괴하중을 산출하였다. 비선형 좌굴해석에 사용된 주 요 물성조건은 Table 2와 같다. 비선형좌굴해석은 Fig. 6과 같이 탄성좌굴해석과 고유치해석을 통하여 좌굴형상을 결정하고 이 를 연계하여 비선형 좌굴해석을 수행하였다. Choi et al.,(2016) 실험의 붕괴하중은 $50.5 \mathrm{MPa}$ 이나 실험이 중단된 것을 감안하여 $60 \mathrm{MPa}$ 의 압력을 부여하였으며 실험조건과 동일하게 바닥면을 고정하였다. 위/아래 덮개와 내압용기의 연결부와 3차 모드에 의한 변형(외부 겉면이 3 방향에서 안쪽으로 진행됨)을 고려하여 내압용기 내부에 접촉조건을 적용하였다. 해석은 상용 유한요 소해석 프로그램인 ANSYS를 사용하였으며 증분량의 크기를 일정한 값으로 제어하여 안정적인 수렴성을 확보할 수 있는 호

Table 2 Conditions of nonlinear buckling analysis

\begin{tabular}{cc}
\hline \hline Material model & Bilinear isotropic hardening \\
\hline Yield stress & $370 \mathrm{MPa}$ \\
Young's modulus & $71 \mathrm{GPa}$ \\
tangential stiffness & $0.5 \mathrm{GPa}$
\end{tabular}

Robe number 3

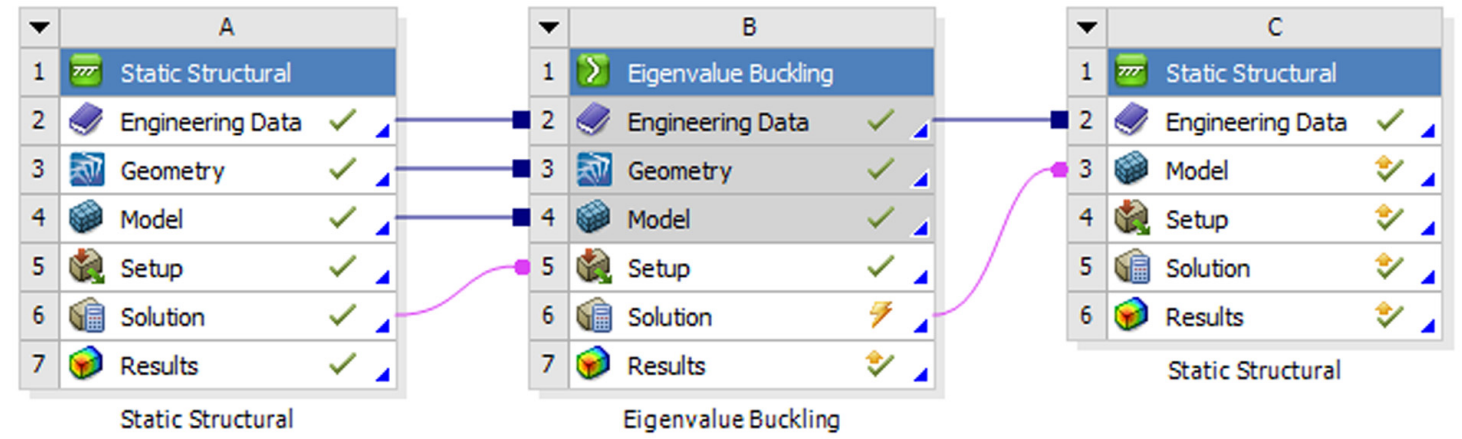

Fig. 6 Procedure of nonlinear buckling analysis

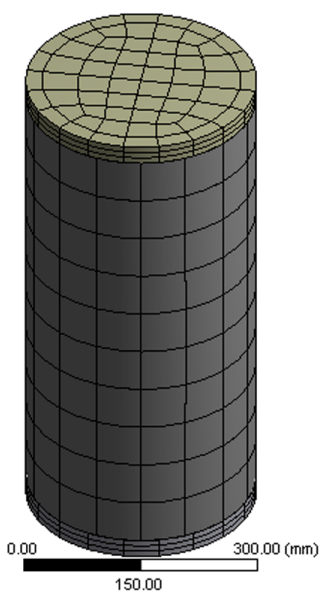

$60 \mathrm{~mm}$

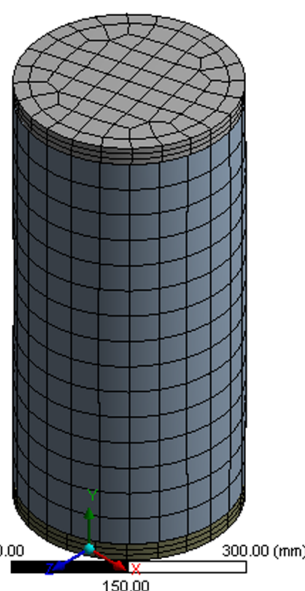

$40 \mathrm{~mm}$

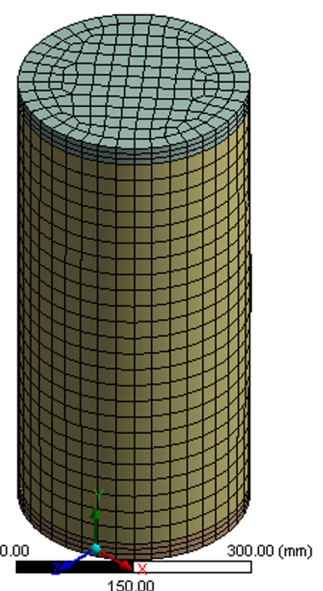

$25 \mathrm{~mm}$

Fig. 7 Elements for mesh test 
장증분법(Arc-Length method)을 사용하였다.

완전 원형단면 내압용기의 경우, Fig. 7 및 Table 3 과 같이 요 소크기에 관계없이 수렴된다. 반면 $1 \mathrm{~mm}$ 의 Imperfection이 있는 단면의 내압용기의 비선형 해석결과는 요소의 대칭성과 크기에 따라 Fig. 8과 같이 변형형상이 달라지므로 대칭성과 요소 크기 를 고려해야한다. 이를 고려하여 작성된 유한요소모델은 Fig. 9 와 같으며 사용된 절점은 111,295 개, 요소는 22,416 개이다.

\section{2 완전 원형단면 내압용기의 비선형 좌굴해석}

일반적인 구조물에서 좌굴은 1 차 모드에서 붕괴가 되면 나머 지 모드들은 큰 의미를 갖기 어려운 것으로 알려졌으나 외압을 받는 덮개가 있는 실린더는 3 차 모드로 붕괴가 된다(Timoshenko and Gere, 1961; Nho et al., 2017). 완전 원형단면 내압용기의 고유 치 해석결과에 따른 3 차 모드 형상은 Fig. 10 과 같으며 Fig. 11

Table 3 Analysis time

\begin{tabular}{cccc}
\hline $\begin{array}{c}\text { Mesh size } \\
{[\mathrm{mm}]}\end{array}$ & Element & $\begin{array}{c}\text { Analysis time } \\
{[\mathrm{s}]}\end{array}$ & $\begin{array}{c}\text { Collapse load } \\
{[\mathrm{MPa}]}\end{array}$ \\
\hline 60 & 1128 & 1056 & 53.72 \\
40 & 1896 & 1054 & 53.66 \\
25 & 4644 & 4838 & 53.65 \\
\hline
\end{tabular}

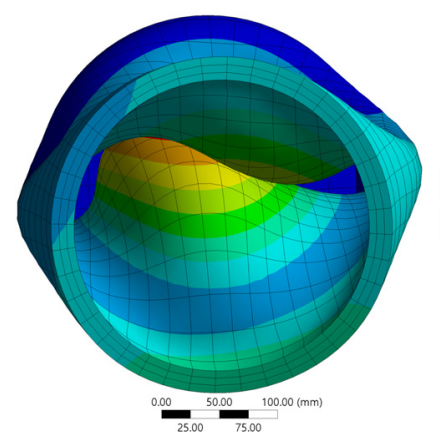

(a) 4,632

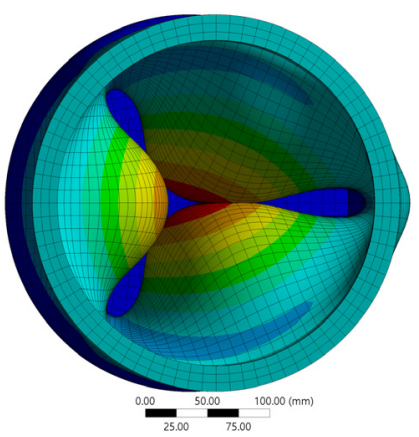

(b) 22,416
Fig. 8 Comparison of deformation shape according to the number of element
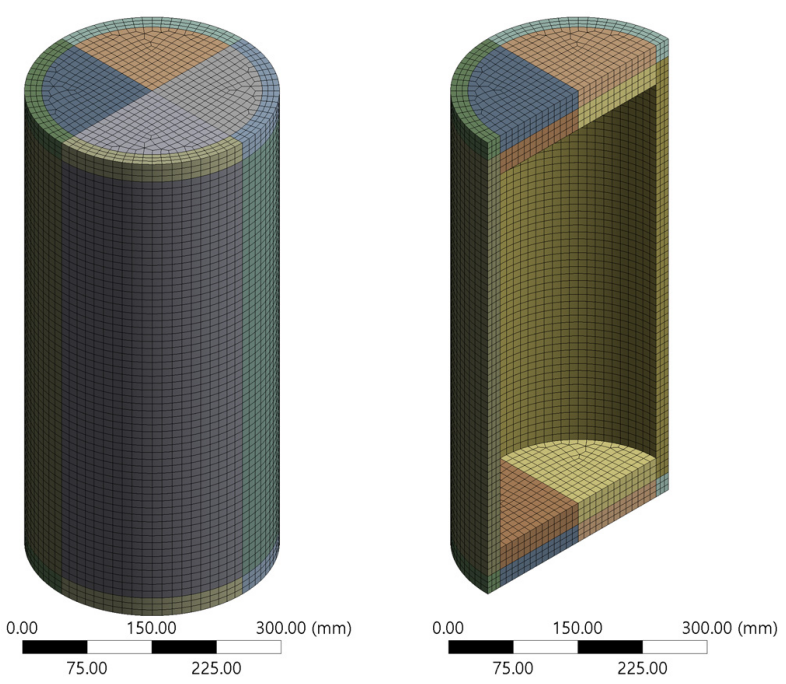

Fig. 9 FEM model

은 해석결과의 변위, 응력, 변형률을 보여주고 있다. Fig. 12는 완전 원형단면 내압용기 비선형 좌굴해석의 변위와 하중 그래 프로 하중이 급격히 감소하는 $53.25 \mathrm{MPa}$ 을 붕괴하중으로 산정할 수 있다.

Fig. 10 Eigenvalue buckling analysis (Perfect section)
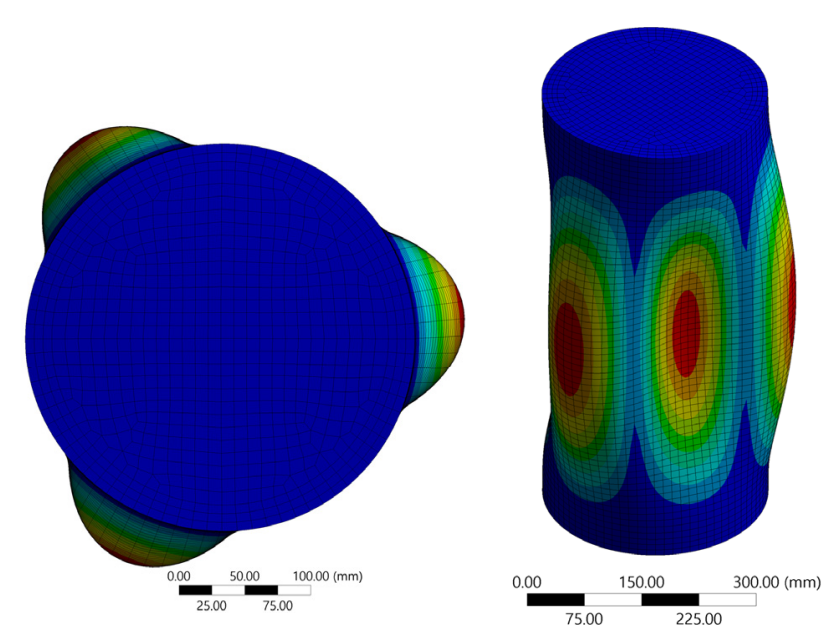

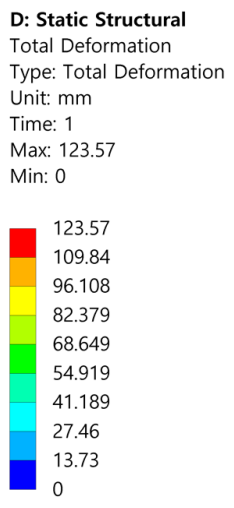

(a) Displacement
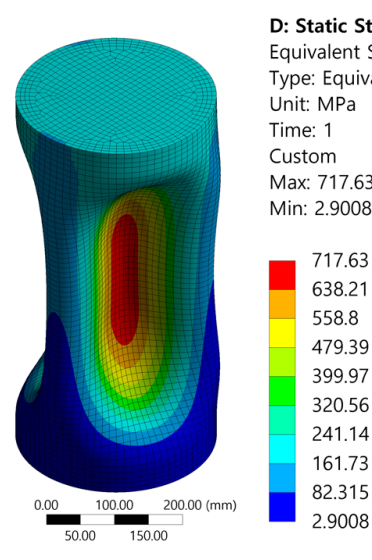$$
\text { (a) Displacement }
$$

Fig. 11 Results of nonlinear buckling analysis (Perfect section)

(b) Stress

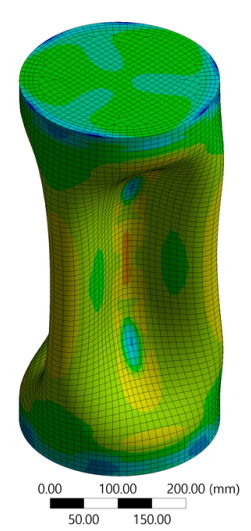

(c) Strain

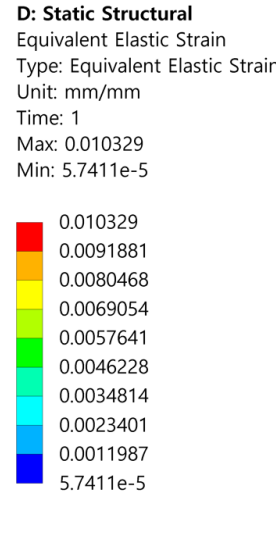

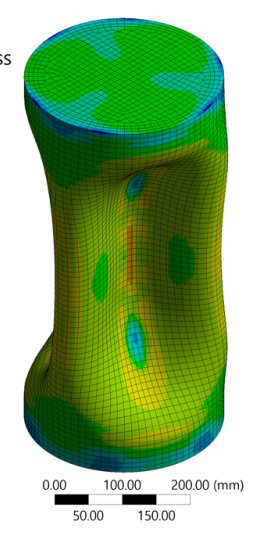

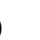




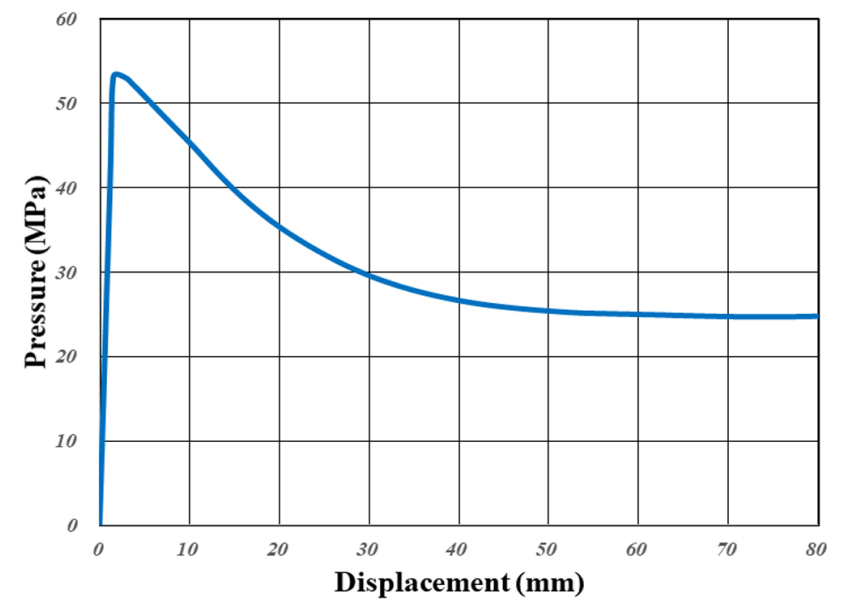

Fig. 12 Displacement-Collapse pressure curve (Perfect section)

\subsection{Imperfection이 있는 내압용기의 비선형 좌굴해석}

완전 원형이 아닌 즉, 난형에 의한 영향을 검토하기 위하여

Table 3과 Fig. 13과 같이 2가지 경우에 대하여 비선형좌굴 해석
을 수행하였다. 일반적으로 기계금속의 제작공차는 0.05 로 매우 작아 난형을 발생시키기에 부족할 것으로 판단하여 제작공차에 비해 비교적 큰 $1 \mathrm{~mm}$ 와 $2.95 \mathrm{~mm}$ 를 대상으로 해석을 수행하였다. 단, 두께는 $20 \mathrm{~mm}$ 로 일정하게 유지하였다.

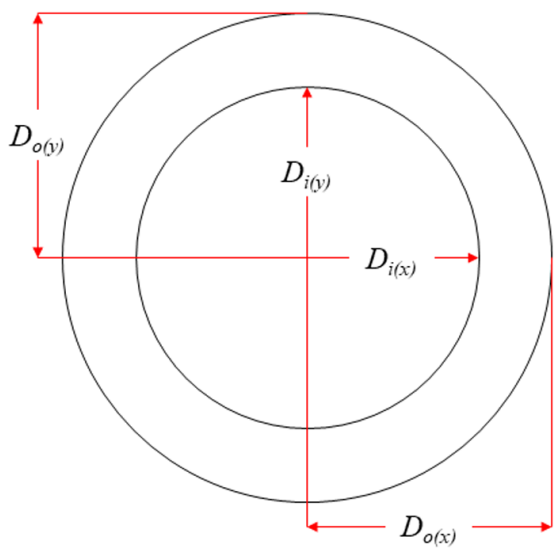

Fig. 13 Variables of imperfection section

Table 4 Dimensions of imperfection section

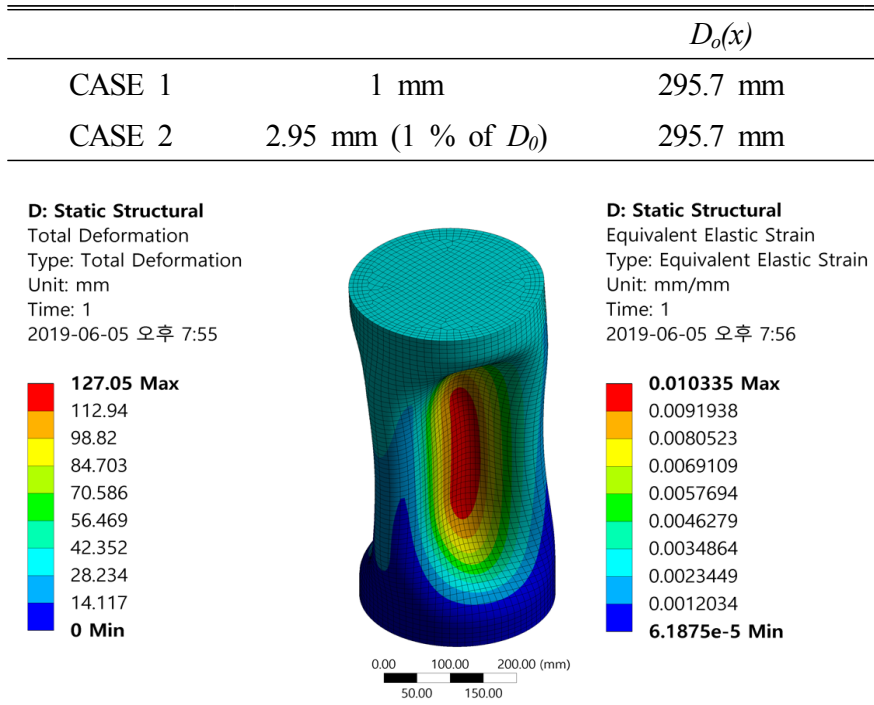

(a) Displacement (b) Stress

$\begin{array}{ccc}D_{o}(y) & D_{i}(x) & D_{i}(y) \\ 294.7 \mathrm{~mm} & 255.7 \mathrm{~mm} & 254.7 \mathrm{~mm} \\ 292.7 \mathrm{~mm} & 255.7 \mathrm{~mm} & 252.7 \mathrm{~mm}\end{array}$

Fig. 14 Results of nonlinear buckling analysis (Imperfect section-Case1)

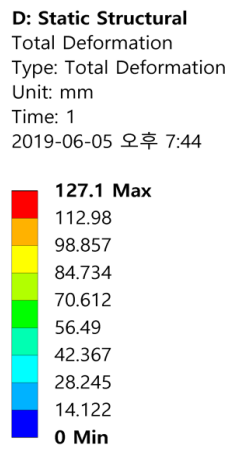

D: Static Structural Type: Total Deformatio Unit: $\mathrm{mm}$ 2019-06-05 오후 7:44

\begin{tabular}{|l|l|}
\hline 127.1 Max \\
112.98 \\
98.857 \\
84.734 \\
70.612 \\
56.49 \\
42.367 \\
28.245 \\
14.122 \\
$\mathbf{0}$ Min \\
\hline
\end{tabular}

(a) Displacement

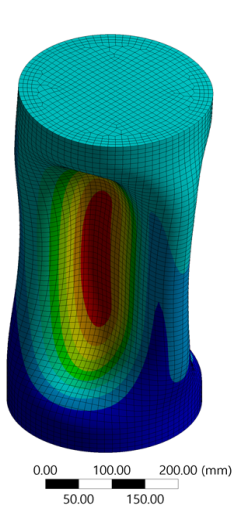

D: Static Structural Equivalent Stress

Type: Equivalent (von-Mises) Stress Unit: $\mathrm{MPa}$ Time: 1 2019-06-05 오후 7:44

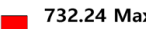

651.26

570.27

570.27
489.29

408.3

327.31

246.33

165.34

84.355

3.3693 Min

(b) Stress

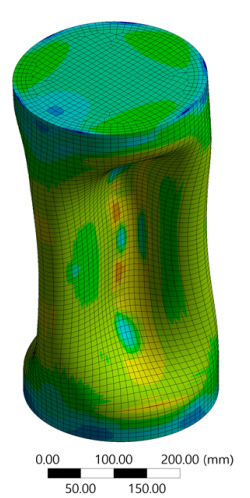

: Static Structural

Equivalent Stress

Type: Equivalent (von-Mises) Stress Unit: $\mathrm{MPa}$

2019-06-05 오후 7:56

733.8 Max

652.62

571.44

490.26

409.09

246.73

165.55

84.366

3.1864 Min (c) Strain

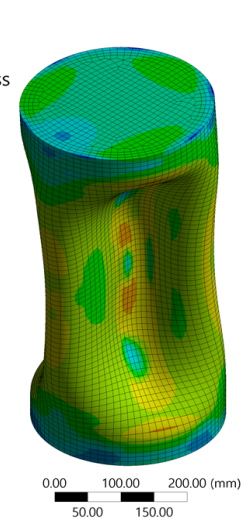




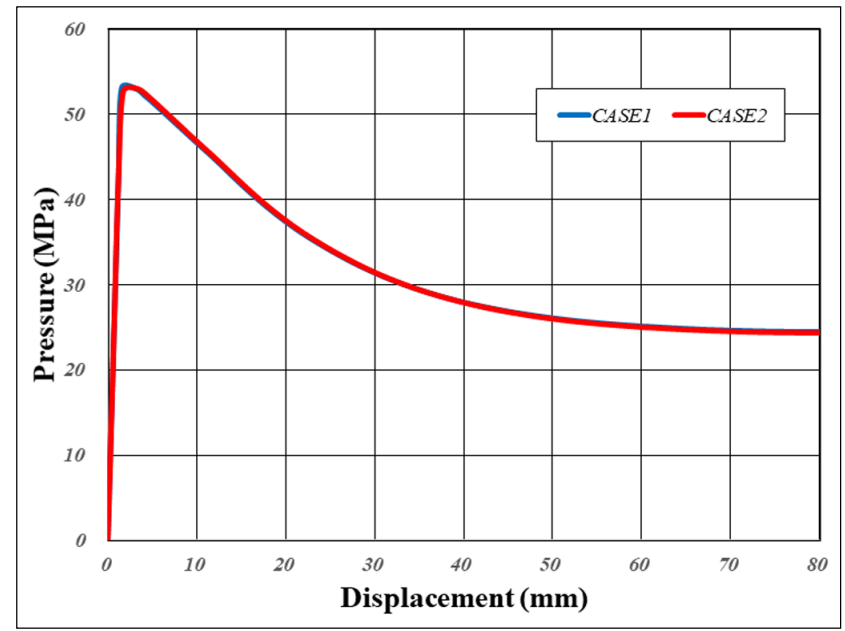

Fig. 16 Displacement-Collapse pressure curve (Imperfect section)

Fig. 14는 Case 1의 비선형 해석결과이며 Fig. 15는 Case 2의 비선형 해석결과이다. 변형형상은 완전 원형단면 내압용기 비 선형좌굴해석 결과(Fig. 11)와 유사하나 난형에 의하여 응력 및 변형량의 분포가 다름을 확인할 수 있다. Fig. 16은 Case 1과 Case 2의 변위 하중곡선을 보여주고 있으며 각각의 붕괴하중은 $53.12 \mathrm{MPa}, 52.96 \mathrm{MPa}$ 로 난형에 의하여 붕괴하중이 감소함을 확 인할 수 있다.

\section{4. 이론식 및 비선형 좌굴해석의 붕괴하중 비교}

압력챔버실험으로 도출된 붕괴하중과 이론식 및 비선형좌굴 해석의 붕괴하중은 Table 5 와 같다.

Table 5에서와 같이 탄성한계하중(식 (11))은 $53.88 \mathrm{MPa}$ 로 실험 의 붕괴하중 $(50.50 \mathrm{MPa})$ 과 비교하여 약 $6.69 \%$ 크게 예측하고 있 으나 완전 원형 단면의 비선형좌굴해석의 붕괴하중( $53.25 \mathrm{MPa})$ 과 는 약 $1.18 \%$ 의 오차를 보인다. 반면 좌굴하중(식 (3))은 $55.77 \mathrm{MPa}$ 로 탄성한계하중 $(53.88 \mathrm{MPa})$ 보다 약 $3.51 \%$ 크게 예측하고 있으며 이를 통하여 좌굴이 탄성한계를 벗어나 발생하는 것으로 유추할 수 있다. 소성붕괴하중(식 (13))은 $62.10 \mathrm{MPa}$ 로 실험의 붕괴하중

Table 5 Collapse pressure

\begin{tabular}{ccc}
\hline \hline & Load $[\mathrm{MPa}]$ & Equation no. \\
\hline Experimental & $50.50 \mathrm{MPa}$ & \\
Buckling pressure & $55.77 \mathrm{MPa}$ & $(3)$ \\
Elastic limit pressure & $53.88 \mathrm{MPa}$ & $(11)$ \\
Plastic collapse pressure & $62.10 \mathrm{MPa}$ & $(13)$ \\
Ovality (1 mm) & $50.05 \mathrm{MPa}$ & $(15)$ \\
Nonlinear buckling analysis & $53.25 \mathrm{MPa}$ & \\
$\quad$ (Perfect section) & & \\
Nonlinear buckling analysis \\
(Imperfection case 1) & $53.12 \mathrm{MPa}$ & \\
Nonlinear buckling analysis & $52.96 \mathrm{MPa}$ & \\
(Imperfection case 2) &
\end{tabular}

과 비교해서는 약 $22.97 \%$, 완전 원형 단면의 비선형좌굴해석에 비해서는 $16.62 \%$ 크게 예측하고 있다. 또한 난형도를 고려한 붕 괴하중(식 (15))는 $50.05 \mathrm{MPa}$ 로 실험결과와 가장 유사하나 실험이 중단된 것을 감안하면 실제보다 작게 예측하고 있다고 판단된다. 위의 분석을 통하여 두꺼운 실린더의 붕괴하중 예측을 위해서는 탄성한계하중식을 적용하는 것이 좋을 것으로 판단된다.

Imperfection을 고려한 비선형좌굴해석인 Case 1과 Case 2의 붕 괴하중은 각각 $53.12 \mathrm{MPa}$ 과 $52.96 \mathrm{MPa}$ 로, 완전원형 단면 비선형좌 굴해석의 붕괴하중에 비하여 $0.24 \%, 0.55 \%$ 감소함을 알 수 있다. 즉, Imperfection이 존재하는 경우, 붕괴하중이 감소함을 확인하였 다. 하지만 가정한 Imperfection의 크기가 일반적인 제작공차에 비하여 매우 크기 때문에 제작상의 이유로 붕괴하중이 줄어들진 않을 것으로 보인다.

\section{5. 강철 원통 실린더 제원(치수) 산출}

Choi et al.(2016)에 활용된 압력챔버는 최대 $60 \mathrm{MPa}$ (수심 $6,000 \mathrm{~m}$ ) 까지 하중을 가할 수 있다. 현재 알루미늄으로 제작된 내압용기의 붕괴하중이 $50.5 \mathrm{MPa}$ 이므로 동일제원의 강철 원통형 내압용기는 실험을 통하여 붕괴 혹은 좌굴의 관측이 불가능하다. 따라서 원통

Table 6 Steel cylinder dimension

\begin{tabular}{cccc}
\hline \hline Outer dia. & $267.4 \mathrm{~mm}$ & Inner dia. & $237.2 \mathrm{~mm}$ \\
Thickness & $15.1 \mathrm{~mm}$ & Length & $600 \mathrm{~mm}$ \\
$E$ & $210 \mathrm{GPa}$ & $E t$ & $1.45 \mathrm{GPa}$ \\
$\sigma_{y}$ & $370 \mathrm{MPa}$ & $\sigma_{u}$ & $410 \mathrm{MPa}$ \\
$D o / t$ & 17 & & \\
\hline
\end{tabular}

Table 7 Estimation of buckling and collapse loads by theory

\begin{tabular}{ccc}
\hline \hline & Load $[\mathrm{MPa}]$ & Equation no. \\
\hline Buckling pressure & 31.7 & $(3)$ \\
Elastic limit pressure & 50.5 & $(11)$ \\
Plastic collapse pressure & 56.8 & $(13)$ \\
Ovality & 41.7 & $(14)$ \\
\hline
\end{tabular}

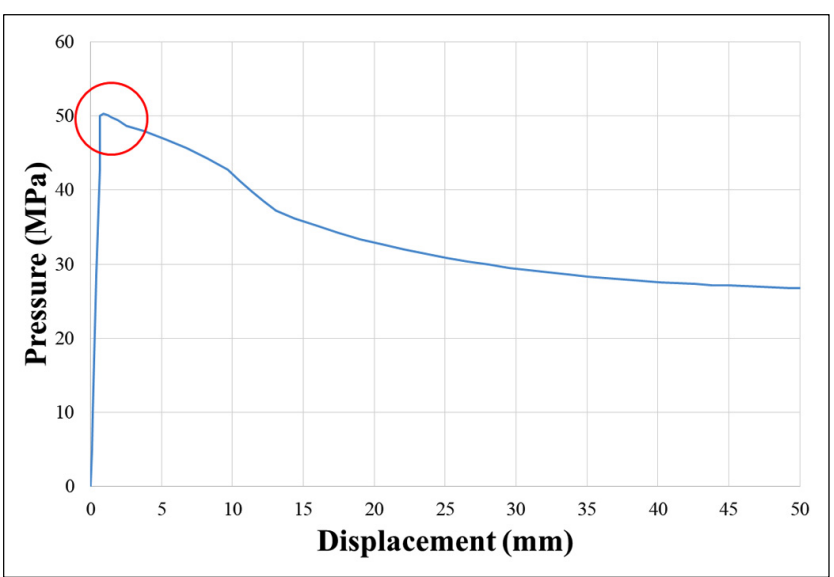

Fig. 17 Collapse pressure (load) of thick steel cylinder 
형 내압용기의 제원 결정 시 이를 고려해야한다. Table 6 의 강철 실린더 치수는 외경 $267.4 \mathrm{~mm}$, 내경 $237.2 \mathrm{~mm}$, 길이 $600 \mathrm{~mm}$, 두께 $15.1 \mathrm{~mm}$, 탄성계수 $210 \mathrm{GPa}$, 소성접선계수 $1.45 \mathrm{GPa}$, 항복강도 $370 \mathrm{MPa}$, 최종강도 $410 \mathrm{MPa}$ 이다. 직경/두께 비 $(D / t=17)$ 로 두꺼운 실린더에 속한다. 이론식에 의해 실린더의 붕괴하중을 예측하면, Table 7과 같이 좌굴하중은 $31.86 \mathrm{MPa}$, 탄성한계하중은 $45.53 \mathrm{MPa}$ 이 며 소성붕괴하중은 $51.20 \mathrm{MPa}$ 이다. 실린더의 제작공차를 $0.1 \%$ 로 가정할 경우(Dmax와 Dmin의 차가 $0.267 \mathrm{~mm})$ 에는 난형도의 붕괴하 중식에 의하여 $40.82 \mathrm{MPa}$ 로 예상된다. 한편 비선형좌굴해석에 의 한 붕괴하중 값은 Fig. 17 에서와 같이 $50.3 \mathrm{MPa}$ 로 산출되며 본 제원 으로 압력챔버 실험을 수행할 경우 붕괴과정을 확인할 수 있을 것으로 보인다.

\section{6. 결 론}

본 연구에서는 정수압을 받는 두꺼운 알루미늄 내압용기의 붕괴하중 값을 도출하기 위하여 다양한 이론식을 조사하고 비 선형 좌굴해석을 수행하여 기 발표된 압력챔버실험 결과와 비 교하였으며 이로부터 다음과 같은 결론을 얻을 수 있다.

(1) 다양한 붕괴하중 이론식 중, 소성붕괴하중식 보다 탄성한 계하중 식이 비선형좌굴해석과 가장 유사함을 확인하였으며 두 꺼운 원통형 내압용기의 붕괴하중 예측을 위해서는 탄성한계하 중식을 사용하는 것이 적정하다고 판단된다.

(2) 난형도가 존재할 경우에는 완전 원형단면의 내압용기의 붕괴하중보다 작아짐을 확인하였다. 하지만 그 영향이 크지 않 아 실제 제작공차로 인한 난형도의 영향은 크지 않음을 알 수 있다.

(3) 난형도를 포함한 해석의 경우, 요소의 질에 따라 최종형상 이 달라질 수 있으므로 요소의 대칭성과 크기가 매우 중요함을 확인하였다.

(4) 두꺼운 강철 내압용기 실험의 붕괴과정 검토를 위하여 비 선형 좌굴해석과 이론식을 통하여 붕괴하중을 산출하여 실험을 위한 제원이 적정함을 확인하였다.

\section{후기}

본 연구는 한국과학재단 '2017년도 이공학개인기초연구’의 후 원으로 수행되었다.

\section{References}

American Society of Mechanical Engineer (ASME), 2010. Rules for Construction of Pressure Vessels. ASME Boiler and Pressure Vessel Code (BPVC), Section 8, Division 1.

Bickell, M.B., Ruiz, C., 1967. Pressure Vessel Design and Analysis.
Macmillan Education.

Choi, H.-J., Lee, J.-H., Kim, J.-M., Lee, S.-G., Maring, K., 2016. The Design, Structural Analysis and High Pressure Chamber Test of a Thick Pressure Cylinder for $2000 \mathrm{~m}$ Water Depth. Journal of the Society of Naval Architects of Korea, 53(2), 144-153. https://doi.org/10.3744/SNAK.2016.53.2.144

Corradi, L., Cammi, A., Luzzi, L., 2011. Collapse Behavior of Moderately Thick Tubes Pressurized from Outside. Nuclear Power - Control, Reliability and Human Factors, Chapter 14, 257-274.

Jeong, T.-H., Lee, J.-H., Noh, I.-S., Lee, J.-M., Lee, P.-M., 2006. A Study on the Structural Design and Analysis of a Deep-sea Unmanned Underwater Vehicle. Journal of Ocean Engineering and Technology, 20(3), 7-14.

Joung, T.-H,. Nho, I.-S., Lee, J.-H., Lee, C.-M., Hyakudome, T., Sammut, K., 2007. Study on the Design, Manufacture, and Pressure Test of a Pressure Vessel Model. Journal of Ocean Engineering and Technology, 21(6),101-106.

Kim, H., Shin, Y., Kim, S., Shin S., Chung, B., Jo, J., Kim, H., 2012, Structural Design of Small Submarine Pressure Hull. Journal of the Society of Naval Architects of Korea, 49(2), 116-123. https://doi.org/10.3744/SNAK.2012.49.2.116.

Lee, J-H., Maring, K., Kim, S., Oh, T., Park, B., 2016. Process of Structural Design and Analysis of Thin Pressure Cylinder for Shallow Sea Usage. Journal of Ocean Engineerign and Technology. 30(3), 201-207. https://doi.org/10.5574/KSOE. 2016.30.3.201

Nho, I., Ryu, J., Lim., S.., Cho, S., Cho, Y., 2017. Buckling Analysis of Circular Cylinders with Initial Imperfection Subjected to Hydraulic Pressure. Journal of the Society of Naval Architects of Korea, 54(3), 267-273. https://doi.org/10.3744/SNAK.2017. 54.3.267

Papadakis, G.. 2008. Buckling of Thick Cylindrical Shells under External Pressure. International Journal of Solids and Structures, 45(20), 5308-5321. https://doi.org/10.1016/j.ijsolstr.2008.05.027

Shin, J.-R., Woo, J.-S., 1999. Collapse Analysis for Deep Sea Pressure Vessel. Journal of Ocean Engineering and Technology. 13(4), 82-97.

Timoshenko, S.P., Gere, J.M., 1961. Theory of Elastic Stability. McGraw-Hill.

Yoo, Y., Huh, N., Choi, Su., Kim, T., Kim, J., 2010. Collapse Pressure Estimates and the Application of a Partial Safety Factor to Cylinders Subject to Experimental Pressure. Nuclear Engineering and Technology, 42(4), 450-459. https://doi.org/ 10.5516/NET.2010.42.4.450 